Check for updates

Cite this: RSC Adv., 2019, 9, 13254

Received 25th February 2019 Accepted 15th April 2019

DOI: $10.1039 / c 9 r a 01395 d$

rsc.li/rsc-advances

\section{In vitro cytotoxicity and antibiotic application of green route surface modified ferromagnetic $\mathrm{TiO}_{2}$ nanoparticles}

\author{
A. K. M. Atique Ullah, (D) ${ }^{* a b}$ A. N. Tamanna, ${ }^{c}$ A. Hossain, ${ }^{d}$ M. Akter, ${ }^{e}$ M. F. Kabir, ${ }^{c}$ \\ A. R. M. Tareq, ${ }^{f}$ A. K. M. Fazle Kibria, ${ }^{9}$ Masaaki Kurasaki, ${ }^{e}$ M. M. Rahman ${ }^{c}$ \\ and M. N. I. Khan ${ }^{\text {h }}$
}

The enormous numbers of applications of $\mathrm{TiO}_{2}$ nanoparticles (NPs) cause concern about their risk to the environment and human health. Consequently, motivated by the necessity of searching for new sources of $\mathrm{TiO}_{2} \mathrm{NPs}$ of low cytotoxicity with antibacterial activity, we synthesized $\mathrm{TiO}_{2} \mathrm{NPs}$ by a green route using a solution of titanium(Iv) isopropoxide as a precursor and an aqueous extract of Artocarpus heterophyllus leaf as a reducing and surface modifying agent. We investigated their structure, shape, size, and magnetic properties, and evaluated their antibiotic application and cytotoxicity. The synthesized $\mathrm{TiO}_{2}$ NPs were applied against two Gram-negative bacteria (E. coli and S. typhimurium) and two Grampositive bacteria ( $S$. aureus and $B$. subtilis) to observe their antibacterial activity; and eventually clear zones of inhibition formed by the $\mathrm{TiO}_{2}$ NPs were obtained. Moreover, after exposing the synthesized $\mathrm{TiO}_{2}$ NPs to HeLa cells (carcinoma cells) and Vero cells (normal cells), no toxic effect was found up to a dose of $1000 \mathrm{mg} \mathrm{L}^{-1}$, indicating the safe use of the samples up to at least $1000 \mathrm{mg} \mathrm{L}^{-1}$. However, toxic effects on HeLa cells and Vero cells were observed at doses of $2000 \mathrm{mg} \mathrm{L}^{-1}$ and $3000 \mathrm{mg} \mathrm{L}^{-1}$. respectively. These results indicate the safe use of Artocarpus heterophyllus leaf extract mediated synthesized $\mathrm{TiO}_{2}$ NPs in their potential applications.

\section{Introduction}

Titanium dioxide $\left(\mathrm{TiO}_{2}\right)$ NPs have wide applications in dye sensitized solar cells and the purification of air and water due to their potential oxidation strength, high photo stability, and non-toxicity. ${ }^{1-3} \quad \mathrm{TiO}_{2}$ NPs also possess interesting optical, dielectric, antimicrobial, antibacterial, chemical stability, and catalytic properties, which lead to industrial applications such as pigments, paints, toothpaste, fillers, catalyst supports,

${ }^{a}$ Nanoscience and Technology Research Laboratory, Atomic Energy Centre, Bangladesh Atomic Energy Commission, Dhaka 1000, Bangladesh. E-mail: atique.chem@gmail. com; atique.chem@baec.gov.bd

${ }^{b}$ Analytical Chemistry Laboratory, Chemistry Division, Atomic Energy Centre, Bangladesh Atomic Energy Commission, Dhaka 1000, Bangladesh

${ }^{c}$ Department of Physics, University of Dhaka, Dhaka 1000, Bangladesh

${ }^{d}$ Department of Physical and Inorganic Chemistry, Institute of Natural Sciences and Mathematics, Ural Federal University, 620000 Yekaterinburg, Russia

${ }^{e}$ Graduate School of Environmental Science, Hokkaido University, 060-0810 Sapporo, Japan

${ }^{f}$ Environmental Organic Chemistry Laboratory, Chemistry Division, Atomic Energy Centre, Bangladesh Atomic Energy Commission, Dhaka 1000, Bangladesh

${ }^{g}$ Nuclear Safety, Security and Safeguards Division, Bangladesh Atomic Energy Commission, Dhaka 1207, Bangladesh

${ }^{h}$ Materials Science Division, Atomic Energy Centre, Bangladesh Atomic Energy Commission, Dhaka 1000, Bangladesh photocatalysts, gas sensors, and optoelectronic devices. ${ }^{4-8}$ This enormous number of applications of $\mathrm{TiO}_{2} \mathrm{NPs}$ may result in the absorption of NPs through the lung or gastrointestinal tract into systematic circulation and then their distribution to different organs, such as the liver, kidneys, spleen, or even the brain, causing localized effects. ${ }^{9}$

The anatase phase of the $\mathrm{TiO}_{2}$ crystal exposes low energy, thereby minimizing the surface energy and increasing the crystal stability. ${ }^{10}$ In addition, the anatase phase is chemically and optically active and hence it is suitable for use as a catalyst and as a support. ${ }^{11}$ The functionality of NPs depends on various factors and among them size, shape, morphology, and crystallinity are notable in depending on the mode of synthesis. ${ }^{\mathbf{1 2 - 1 4}}$ $\mathrm{TiO}_{2}$ NPs have been synthesized by using sol-gel, microemulsion, chemical precipitation, hydrothermal, solvothermal, electrochemical, and biological synthesis methods. ${ }^{15}$ Among all these methods, the green synthesis of nanomaterials, usually known as bio-synthesis, is gaining attention from researchers because of its simplicity, speed, non-toxicity, and economical approach. ${ }^{16}$ Bio-syntheses of NPs by bacteria, fungi, yeast, or plant extracts are the best alternatives to develop cost-effective, less laborious, non-toxic, and environmentally friendly NPs for avoiding adverse effects in many nanomaterial applications. ${ }^{\mathbf{1 7}}$ The synthesis of NPs using plant extracts is more effective than using microbes, because the presence of biomolecules in plants 
can act as a reducing agent as well as a stabilizer and thus enhance the rate of reduction and stabilization of the NPs. ${ }^{18}$

As an important component in the development of nanotechnology, NPs have been extensively explored for possible medical applications. Magnetic nanoparticles are considered to be more effective for bio-medical applications. NPs provide a particularly useful platform and demonstrate unique properties with potentially wide-ranging therapeutic applications. ${ }^{\mathbf{1 9}}$ Antibiotic resistant bacterial strains with different mechanisms are continually being found and thus new drugs are required. ${ }^{20}$ Therefore, the finding of new antimicrobial agents with novel mechanisms of action is essential and is being extensively pursued in antibacterial drug discovery. ${ }^{21}$ Recently, it has been demonstrated that metal oxide NPs exhibit excellent biocidal and biostatic actions against Gram-positive and Gram-negative bacteria. ${ }^{22}$ Several reports are available for the synthesis of $\mathrm{TiO}_{2}$ NPs using plant/leaf extracts of Nyctanthes arbor-tristis, Solanum trilobatum, Annona squamosa, Catharanthus roseus, Calotropis gigantea, and Jatropha curcas. ${ }^{23-28}$

In the present study, Artocarpus heterophyllus leaf extract was used as a reducing and surface modifying agent. To the best of our knowledge, this is the first report where Artocarpus heterophyllus leaf aqueous extract was used as a reducing and surface modifying agent in the synthesis of $\mathrm{TiO}_{2} \mathrm{NPs}$. Artocarpus heterophyllus, commonly known as jackfruit, belongs to the Moraceae family and is widely cultivated and grows in the tropical regions of the world. ${ }^{29}$ Consequently, the effect of bio-synthesized $\mathrm{TiO}_{2}$ NPs was investigated against different types of human pathogens. Moreover, their cytotoxicity was investigated by applying them to two types of cell line: human carcinoma cells (HeLa) and normal cells (Vero) in order to find out about their anticancer activity and toxicity threshold limit, respectively.

\section{Materials and methods}

\section{Materials}

Artocarpus heterophyllus (jackfruit) leaves were collected locally from Dhaka, Bangladesh. Titanium(Iv) isopropoxide (TTIP) was purchased from Merck, India. Bactotrypton, bacto agar, and yeast extract were purchased from Difco Laboratories (Detroit, MI, USA) and sodium chloride from the Wako Pure Chemical Company (Osaka, Japan). HeLa cell and Vero cell lines were obtained from the American type culture collection (USA and Canada). Dulbecco's modified Eagle's medium (DMEM) was purchased from Sigma (St. Louis, MO, USA). Fetal bovine serum was purchased from Biosera (Kansas City, MO, USA). Trypan blue stain solution (4\%) was purchased from Bio-Rad (Hercules, CA, USA). All other chemicals and reagents were of analytical grade.

\section{Synthesis of $\mathrm{TiO}_{2}$ nanoparticles}

The collected leaves were gently washed with de-ionized water to remove the dust and then sun-dried for about 10 days under dust-free conditions. Then the dried leaves were ground and sieved to get the finest powder. $10 \mathrm{~g}$ of the powdered leaves were mixed with $500 \mathrm{~mL}$ of de-ionized water and heated to $100{ }^{\circ} \mathrm{C}$ for $30 \mathrm{~min}$ and cooled to room temperature. The mixture was then filtered through Whatman no. 1 filter paper and the filtrate termed here as leaf extract was stored at $4{ }^{\circ} \mathrm{C}$ for further experiments. The leaf extract was added drop-wise into $0.5 \mathrm{M}$ TTIP solution at a ratio of $4: 1$ under constant magnetic stirring at $100{ }^{\circ} \mathrm{C}$. Then the room temperature cooled mixture was washed repeatedly with de-ionized water and centrifuged in order to remove the impurities. The obtained sample was dried at $105^{\circ} \mathrm{C}$ in a hot air oven and finally calcined at $650{ }^{\circ} \mathrm{C}$ for $3 \mathrm{~h}$.

\section{Characterization of $\mathrm{TiO}_{2}$ nanoparticles}

The optimum calcination temperature for the formation of nano $\mathrm{TiO}_{2}$ anatase phase was obtained from a thermogravimetric analysis, which was carried out under an $\mathrm{N}_{2}$ atmosphere using a TA instrument (SDR Q-600) operating from $25^{\circ}$ to $800^{\circ} \mathrm{C}$ with a heating rate of $10^{\circ} \mathrm{C} \mathrm{min}^{-1}$. The elemental analysis of the sample was obtained from energy dispersive X-ray (EDX) spectroscopy measurements, performed by a JEOL JSM $7600 \mathrm{~F}$ instrument (Japan), using an acceleration voltage of $15 \mathrm{kV}$ and an emission current of $12 \mu \mathrm{A}$. In order to analyze the functional groups in the leaf extract, which can act as reducing and surface modifying agents, their presence was confirmed by Fourier transform - infrared (FT-IR) analysis using a JASCO-FTIR-6300 instrument (Japan) on $\mathrm{KBr}$ pellets. 1\% (w/w) samples were mixed with $\mathrm{KBr}$ powder and pressed into a sheer slice. FT-IR analysis of the sample was also carried out in order to confirm the formation of $\mathrm{TiO}_{2}$ with surface modification. The crystalline phase was assessed by an X-ray powder diffractometer (Philips PANalytical X'PERT PRO) equipped with $\mathrm{CuK}_{\alpha}$ radiation $(1.5418 \AA)$. The surface morphology was monitored by field emission scanning electron microscopy using a JEOL model JSM $7600 \mathrm{~F}$ instrument (Japan), applying an acceleration voltage of $15 \mathrm{kV}$ and an emission current of $12 \mu \mathrm{A}$. The particle size was calculated from the transmission electron microscopy (TEM) analysis using a JEOL JEM 2010 instrument (Japan) recorded at an accelerating voltage of $120 \mathrm{kV}$. The magnetic property of the $\mathrm{TiO}_{2}$ NPs was evaluated using a Vibrating Sample Magnetometer (EV-9 MicroSense, German).

\section{Antibacterial activity of $\mathrm{TiO}_{2}$ NPs}

The antibacterial activity of the $\mathrm{TiO}_{2}$ NPs was evaluated by considering four types of bacteria: Escherichia coli (ATCC 25922), Salmonella typhimurium (ATCC 14028), Staphylococcus aureus (ATCC 12228), and Bacillus subtilis (ATCC 14579) following the disc diffusion method described elsewhere. ${ }^{29}$ Briefly, bacteria were cultured in Luria Broth (LB) medium (tryptone $1.5 \%$, yeast extract $0.75 \%$, sodium chloride $1.2 \%$ ) in a $60 \mathrm{rpm}$ shaking water bath at $37^{\circ} \mathrm{C}$. Then, $50 \mu \mathrm{L}$ of bacterial medium was poured onto a Petri plate and smoothly smeared by a glass rod. $7 \mathrm{~mm}$ sized sterilized filter papers were soaked in $15 \mu \mathrm{L}$ of $\mathrm{TiO}_{2} \mathrm{NP}$ suspension and placed on a culture plate for $24 \mathrm{~h}$. Deionized water discs and commercial antibiotic discs were used as negative and positive controls, respectively.

\section{Cytotoxicity of $\mathrm{TiO}_{2} \mathrm{NPs}$}

The cytotoxicity of the $\mathrm{TiO}_{2}$ NPs was assessed from a cell viability experiment following a Trypan blue exclusion assay. ${ }^{30}$ 
The cells were cultured in DMEM medium supplemented with $10 \%$ FBS in a humidified incubator at $37{ }^{\circ} \mathrm{C}$ with $5 \% \mathrm{CO}_{2}$ in 25 $\mathrm{cm}^{2}$ culture flasks. Then, the $\mathrm{TiO}_{2}$ NPs were added into the flasks, and incubated for $48 \mathrm{~h}$. In every treatment, fresh medium was added prior to treatment. After $48 \mathrm{~h}$, the cell viability was measured using a Bio-Rad automated cell counter (Hercules CA, USA). Cell viability was expressed as a percentage of the total cell counts against the stained cell counts. Each experiment was performed at least three times to ensure reproducibility and statistical validity.

\section{Results and discussion}

The temperature-dependent weight losses of the sample using TGA have been shown in Fig. 1. The slope of the TG curve indicates that the weight losses of the studied sample could be clearly seen at different stages up to $650{ }^{\circ} \mathrm{C}$. About $7 \%$ weight loss was noticed up to $100{ }^{\circ} \mathrm{C}$, which is related to the release of water molecules attached to the surface of the synthesized sample. Weight loss up to $350{ }^{\circ} \mathrm{C}$ occurs due to the release of unreacted organic molecules present in the sample. Then the weight loss up to $550{ }^{\circ} \mathrm{C}$ is attributed to both the decomposition of the residual biomolecules and the crystallization of the sample. Sharp changes in weight loss from the TG plot were observed from $550{ }^{\circ} \mathrm{C}$ to $650{ }^{\circ} \mathrm{C}$ which were attributed to the condensation of the anatase phase of $\mathrm{TiO}_{2} \cdot{ }^{31}$ Based on this result, $650{ }^{\circ} \mathrm{C}$ was selected as the calcination temperature for the synthesis of $\mathrm{TiO}_{2}$ NPs.

The EDX spectra show two intense peaks at 4.51 and $0.53 \mathrm{keV}$ corresponding to the presence of $\mathrm{Ti}$ and $\mathrm{O}$, respectively (Fig. 2). The atomic percentages of $\mathrm{Ti}$ and $\mathrm{O}$ were 32 and 43, respectively, indicating the formation of non-stoichiometric $\mathrm{TiO}_{2}$ with oxygen vacancies, which leads to better photocatalytic activity. ${ }^{32}$ Two less intense peaks obtained at 0.28 and $0.39 \mathrm{keV}$ are assigned as $\mathrm{C}$ and $\mathrm{N}$, respectively. These impure elements originated from the leaf extract and depict their conjunction with the synthesized $\mathrm{TiO}_{2} \mathrm{NPs}^{29}$

The FT-IR spectra of $A$. heterophyllus leaf powder are shown in Fig. 3a. The spectra clearly demonstrate that three strong peaks appeared at 3768,3693 and $3435 \mathrm{~cm}^{-1}$, corresponding to $\mathrm{N}-\mathrm{H}$ stretching of amide, $-\mathrm{OH}$ stretching vibration (phenolic

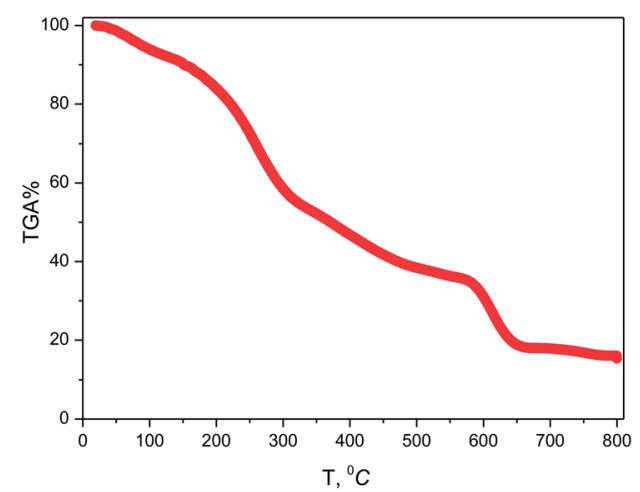

Fig. 1 TGA plot of $\mathrm{TiO}_{2}$ NPs synthesized using Artocarpus heterophyllus leaf extract and $\mathrm{Ti}\left[\mathrm{OCH}\left(\mathrm{CH}_{3}\right)_{2}\right]_{4}$ solution.

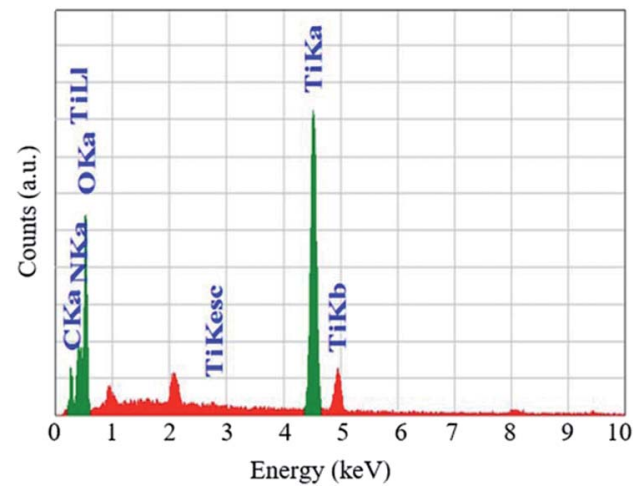

Fig. 2 EDX spectra of $\mathrm{TiO}_{2} \mathrm{NPs}$ and bioorganic components of Artocarpus heterophyllus leaf extract.

compounds), and -OH stretching of water, and other intense peaks appeared at 2924 and $2856 \mathrm{~cm}^{-1}$, corresponding to the $\mathrm{C}-\mathrm{H}$ stretching vibration and alkynes (flavonoids) which were reported as active reducing and capping agents. ${ }^{33-35}$

The details of peaks appearing for A. heterophyllus leaf powder and synthesized $\mathrm{TiO}_{2}$ NPs are summarized in Table 1. Fig. 3b demonstrates that peaks almost similar to those of leaf powder appeared for synthesized $\mathrm{TiO}_{2}$ NPs at 3757, 3693, 3435, $2926,2858,1624$, and $1433 \mathrm{~cm}^{-1}$. This observation implies that the peaks correspond to the biomolecules acting as capping and
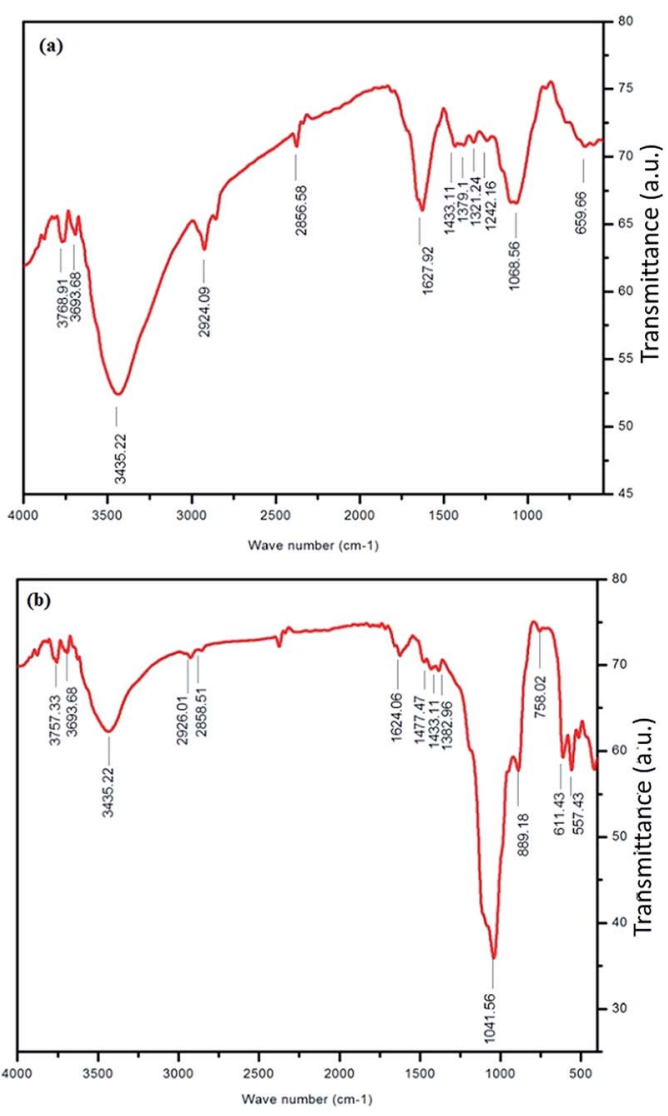

Fig. 3 FT-IR spectra of (a) A. heterophyllus (AH) leaf powder and (b) $\mathrm{TiO}_{2}$ NPs indicating the conjugation of biomolecules with $\mathrm{TiO}_{2} \mathrm{NPS}$ obtained from $\mathrm{AH}$ leaf extract. 
Table 1 Summary of FT-IR interpretation of $A$. heterophyllus leaf powder and $\mathrm{TiO}_{2} \mathrm{NPs}$

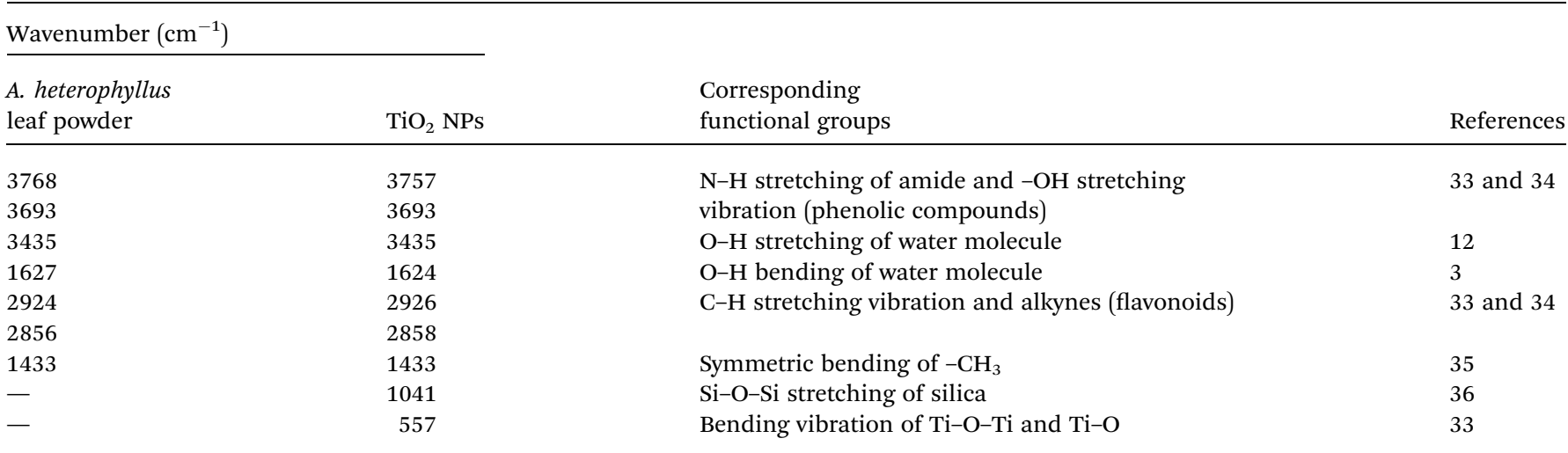

stabilizing agents in $\mathrm{TiO}_{2} \mathrm{NPs}^{29}$ Moreover, two additional strong peaks observed at 557 and $1041 \mathrm{~cm}^{-1}$ in Fig. $3 \mathrm{~b}$ are due to the vibration of $\mathrm{Ti}-\mathrm{O}-\mathrm{Ti}$ and $\mathrm{Si}-\mathrm{O}-\mathrm{Si}$, respectively. ${ }^{33,36}$ The vibration band of Ti-O-Ti firmly proves the formation of $\mathrm{TiO}_{2}$ NPs.

It is important to note that the intensity of the almost similar peaks appearing for leaf powder and $\mathrm{TiO}_{2}$ NPs was found to decrease in the $\mathrm{TiO}_{2}$ NPs sample. Another peak with the highest intensity appearing for $\mathrm{TiO}_{2} \mathrm{NPs}$, corresponding to the $\mathrm{Si}-\mathrm{O}-\mathrm{Si}$ stretching vibration, might be due to the presence of silica. Probably the leaf extract contains silicon which becomes silica after calcination. This residual silica might be responsible for the stability of $\mathrm{TiO}_{2}$ NPs, which agrees well with the TG analysis.

The inspection of the XRD data was first carried out by the phase identification method. This procedure helped us to determine the presence of the mixed phase of $\mathrm{TiO}_{2}$. We refined the XRD patterns using the FullProf program in profile matching mode. ${ }^{37}$ Fig. 4 shows the refinement of the Artocarpus heterophyllus leaf extract mediated synthesized mixed phase of $\mathrm{TiO}_{2}$. We found better fitting of the refinement using the cell parameters of anatase and panguite type mixed phase. We refined the XRD patterns using the reported cell parameters of anatase $^{38}$ and panguite ${ }^{39}$ phases. Although several research groups reported the different phases of $\mathrm{TiO}_{2}$ performing

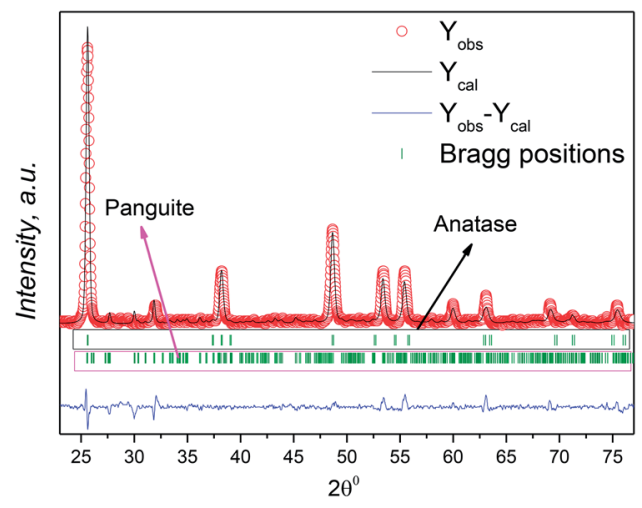

Fig. 4 Refined XPRD profiles of Artocarpus heterophyllus leaf extract mediated synthesized mixed phase $\mathrm{TiO}_{2}$ NPs. The open red circles, black lines, the bottom blue line, and green vertical bars represent the experimental data, calculated pattern, difference curves, and Bragg positions, respectively. different synthesis conditions, the panguite phase is reported as a mixed metallic phase by Ma et al. ${ }^{39}$ According to their reports, this mixed metallic phase is one of the oldest materials in the solar system and is formed by condensation. The highest intensity peak (Fig. 4) of the panguite phase near $33^{\circ}$ is very small compared with the main phase, which implies that a small amount of panguite phase is synthesized as an impurity. This mixed phase might originate from the use Artocarpus heterophyllus leaf extract in the synthesis of $\mathrm{TiO}_{2}$ NPs. The unit cell parameters, space group and $R$ factor are summarized in Table 2 using two-phase model-based profile matching refinement.

Fig. 5a shows the FESEM image of the synthesized $\mathrm{TiO}_{2} \mathrm{NPs}$ with a high degree of crystallinity in which the surface morphology is found to be uniformly distributed with nano dimensions. The TEM image (Fig. 5b) clearly demonstrates that the synthesized $\mathrm{TiO}_{2}$ NPs are spherical in shape with smooth edges and are uniformly distributed. The particle sizes of the synthesized $\mathrm{TiO}_{2}$ NPs are in the approximate range of 15 to $20 \mathrm{~nm}$, which is in good agreement with the crystallite size (15 $\mathrm{nm}$ ) calculated using the XRD patterns. An intense look at the TEM image reveals that surface modification of the synthesized $\mathrm{TiO}_{2}$ NPs was also obtained. The synthesized $\mathrm{TiO}_{2}$ NPs are found to be less agglomerated, which might be due to the presence of biomolecule content capping agents on the surface of the $\mathrm{TiO}_{2}$ NPs, as evidenced from the FT-IR and EDX analyses. It is worth mentioning here that the capping is found to be present even when the materials are calcined at high temperature, indicating their high temperature stability.

Room-temperature VSM measurement of our studied $\mathrm{TiO}_{2} \mathrm{NPS}$ is represented in Fig. 6. This figure demonstrates that the studied $\mathrm{TiO}_{2}$ NPs have a very weak ferromagnetic nature at room temperature. Fig. 6 (inset) shows an enlarged view of the hysteresis loop obtained from VSM measurement at room temperature. These types of materials have been reported as diluted magnetic semiconductors with a room-temperature ferromagnetism nature, and are interesting materials for spintronic applications. ${ }^{40}$ Although the origin of the magnetic behaviour is not clear, shallow defects, such as oxygen vacancies, might be the reason for the dilute ferromagnetic nature. ${ }^{41}$ It has been established that magnetic nanoparticles are among promising materials for medical applications. So, the magnetic measurements fulfilled our aim towards the study of dilute ferromagnetic $\mathrm{TiO}_{2} \mathrm{NPs}$. 
Table 2 The unit cell parameters and volume $R$-factors refined by the profile matching method for the Artocarpus heterophyllus leaf extract mediated synthesized mixed phase $\mathrm{TiO}_{2} \mathrm{NPs}$

\begin{tabular}{|c|c|c|c|c|c|c|c|}
\hline Phase & Space group & $a, \AA$ & $b, \AA$ & $c, \AA$ & $\frac{\text { Cell volume }}{V, \AA^{3}}$ & $R_{\mathrm{B}} \%$ & $R_{\mathrm{f}} \%$ \\
\hline Panguite & $P b c a$ & 9.49192 & 9.77530 & 9.93117 & 921.477 & 6.88 & 3.56 \\
\hline
\end{tabular}

(a)

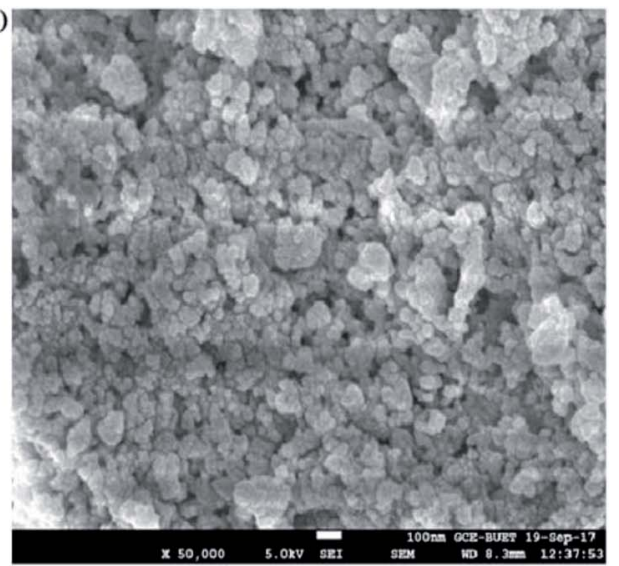

(b)

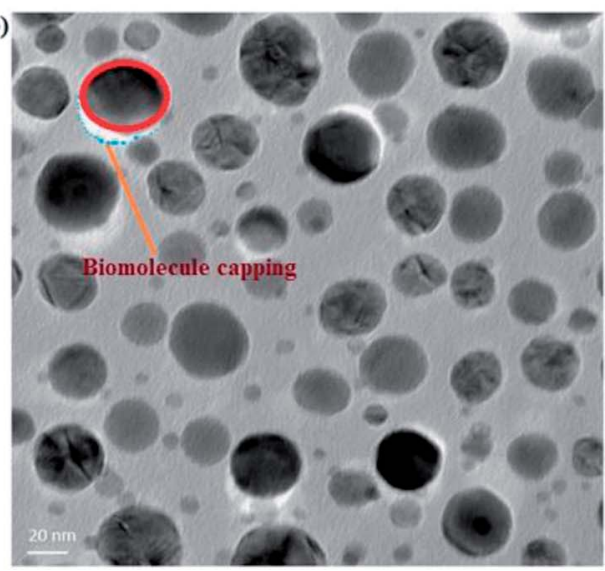

Fig. 5 (a) FESEM image and (b) TEM image of $\mathrm{TiO}_{2}$ NPs synthesized using $A$. heterophyllus leaf extract and $\mathrm{Ti}\left[\mathrm{OC} \mathrm{CH}\left(\mathrm{CH}_{3}\right)_{2}\right]_{4}$ solution.

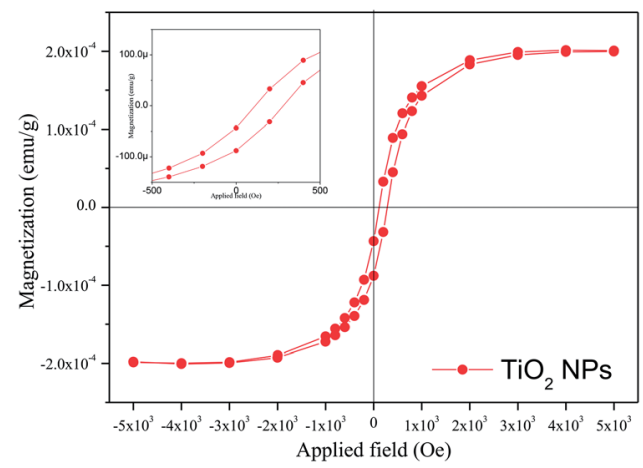

Fig. 6 The room-temperature magnetization curve of $\mathrm{TiO}_{2} \mathrm{NPs}$ synthesized using $A$. heterophyllus leaf extract and $\mathrm{Ti}\left[\mathrm{OCH}\left(\mathrm{CH}_{3}\right)_{2}\right]_{4}$ solution. The inset shows an enlarged view of the hysteresis loop.
The antibacterial activity of green synthesized $\mathrm{TiO}_{2} \mathrm{NPs}$ surface modified by Artocarpus heterophyllus leaf extract was investigated against both Gram-negative $(E$. coli and $S$. typhimurium) and Gram-positive (S. aureus and B. subtilis) bacteria using an agar well diffusion assay. The observed zones of inhibition corresponding to experimental bacteria are shown in Fig. 7. However, the negative control (deionized water) did not show any zone of inhibition and the positive control (ampicillin) exhibited antibacterial activity against the four investigated human pathogens. Furthermore, the leaf extract used for the surface modifying agent of $\mathrm{TiO}_{2} \mathrm{NPs}$ was also exposed on the two types of bacteria, where no zone of inhibition was found, confirming the antibacterial activity of $\mathrm{TiO}_{2}$ NPs. The antibacterial activity of the sample was compared with the other bio-synthesized $\mathrm{TiO}_{2}$ NPs and is summarized in Table 3 . The results clearly demonstrate that the efficiency of the currently studied Artocarpus heterophyllus leaf extract surface modified $\mathrm{TiO}_{2}$ NPs has potential antibiotic activity against both Gram-positive and Gram-negative bacteria.

The antibacterial activity of surface modified $\mathrm{TiO}_{2} \mathrm{NPs}$ is supposed to be achieved through multiple mechanisms of phytochemicals and $\mathrm{TiO}_{2}$ NPs. It is assumed that the phytochemicals are capable of binding with the bacterial cell wall and then penetrating into the bacterial cells. ${ }^{42}$ In the course of time, $\mathrm{TiO}_{2}$ NPs act as a catalyst to inactivate the enzymes of microorganisms that resist metabolism by interacting with the thiol groups of proteins, disrupting bacterial membranes and also affecting DNA replication. ${ }^{42}$ The $\mathrm{TiO}_{2}$ NPs are reported as being more effective material against Gram-negative bacteria than against Gram-positive bacteria because of the rigid, thick, multiple layers of peptidoglycan in the cell walls of Grampositive bacteria preventing the nanoparticles from entering into the cell wall. ${ }^{43}$

The synthesized $\mathrm{TiO}_{2}$ NPs were applied to HeLa cells and Vero cells with different concentrations of NPs starting from $1 \mathrm{mg} \mathrm{L}^{-1}$ to $5000 \mathrm{mg} \mathrm{L}^{-1}$ and the cell viability was measured for cytotoxicity assessment. The phase contrast microscopic images of $\mathrm{TiO}_{2} \mathrm{NP}$ induced cytomorphological changes and growth inhibition of two cell lines with control, leaf extract and at different concentrations of $\mathrm{TiO}_{2}$ NPs are shown in Fig. 8.

The cell viability indicates that the synthesized $\mathrm{TiO}_{2}$ NPs are not toxic against the two selected cell lines up to $1000 \mathrm{mg} \mathrm{L}^{-1}$. This result implies that our synthesized $\mathrm{TiO}_{2}$ NPs could be used for various applications with concentrations up to $1000 \mathrm{mg} \mathrm{L}^{-1}$ without any toxicity. The synthesized $\mathrm{TiO}_{2} \mathrm{NPs}$ at $2000 \mathrm{mg} \mathrm{L}^{-1}$ 

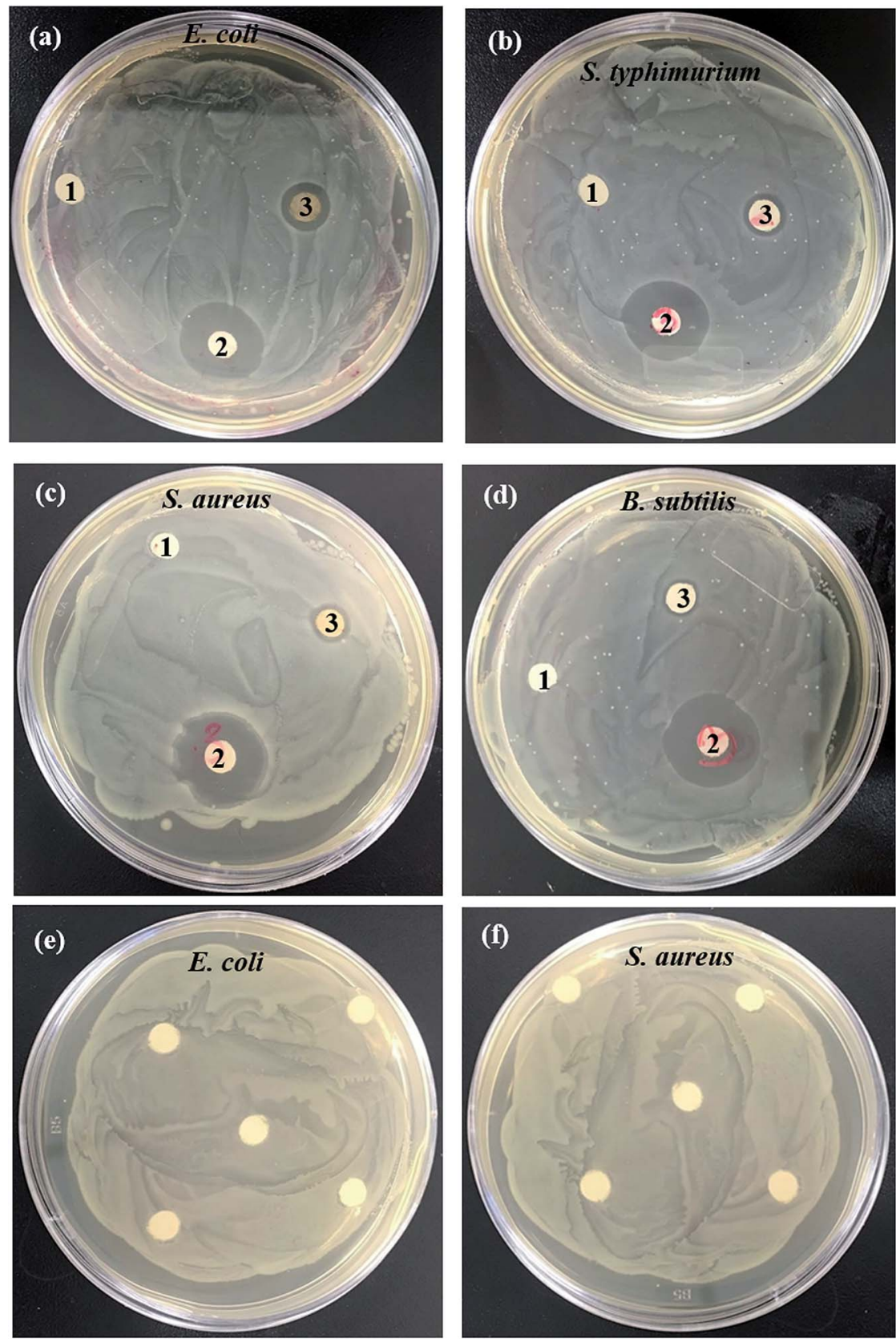

Fig. 7 Antibacterial activity of 1 deionized water, 2 ampicillin and $3 \mathrm{TiO}_{2} \mathrm{NPs}$ against Gram-negative (a) E. coli and (b) S. typhimurium, and Grampositive (c) S. aureus and (d) B. subtilis pathogenic bacteria; (e, f) exposure of leaf extract against $E$. coli and $S$. aureus.

are found to be toxic with a decrease in cell viability of around $10 \%$ against the carcinoma HeLa cell line, but the same concentration of $\mathrm{TiO}_{2}$ NPs does not affect activity against the Vero cell line. In the case of the Vero cell line, the synthesized $\mathrm{TiO}_{2}$ NPs showed toxicity at a dose of $3000 \mathrm{mg} \mathrm{L}{ }^{-1}$. The cell viability is found to decrease with an increase in concentration for both cell lines. In order to confirm whether the toxicity arose from the $\mathrm{TiO}_{2}$ NPs or the leaf extract, Artocarpus heterophyllus aqueous leaf extract was further applied to both cell lines. For the treatment with leaf extract there was no change in cell viability observed in comparison to the control, indicating that
$\mathrm{TiO}_{2}$ NPs were responsible for the cytotoxicity. Although the cytotoxicity of $\mathrm{TiO}_{2}$ NPs has been investigated extensively, the precise mechanisms where $\mathrm{TiO}_{2}$ NPs induce cell death are mostly unclear, as the cytotoxicity varies from cell to cell as well as from NPs to NPs. ${ }^{47}$ The cytotoxic effect of $\mathrm{TiO}_{2}$ NPs is mainly due to the disruption of the antioxidant system. ${ }^{48}$ Thus, oxidative stress increases the consequences of cellular-level oxidative stress in free radical mediated membrane damage, including mitochondrial and plasma membranes, which results in damage to cellular protein, lipids and DNA and finally leads to cell death and dysfunction of the electronic chain. ${ }^{48}$ The 
Table 3 Various phyto-synthesized $\mathrm{TiO}_{2} \mathrm{NP}$ induced zones of inhibition against different harmful human pathogenic bacteria

\begin{tabular}{|c|c|c|c|c|}
\hline $\begin{array}{l}\text { Name of various } \\
\text { pathogenic bacteria }\end{array}$ & Extracted substances & $\begin{array}{l}\text { Concentrations } \\
\text { of } \mathrm{TiO}_{2} \text { NPs }\left(\mathrm{mg} \mathrm{L}^{-1}\right)\end{array}$ & $\begin{array}{l}\text { Zone of } \\
\text { inhibition }(\mathrm{mm})\end{array}$ & References \\
\hline \multirow[t]{3}{*}{ E. coli } & M. citrifolia & 100 & 9 & 33 \\
\hline & A. flavus & 40 & 35 & 44 \\
\hline & A. heterophyllus & 100 & 23 & Present work \\
\hline \multirow[t]{2}{*}{ S. typhimurium } & A. niger & 40 & 18 & 45 \\
\hline & A. heterophyllus & 100 & 20 & Present work \\
\hline \multirow[t]{4}{*}{ S. aureus } & M. citrifolia & 100 & 12 & 33 \\
\hline & A. flavus & 40 & 25 & 44 \\
\hline & H. rosa-sinensis & 20 & 11 & 46 \\
\hline & A. heterophyllus & 100 & 17 & Present work \\
\hline \multirow[t]{4}{*}{ B. subtilis } & M. citrifolia & 100 & 10 & 33 \\
\hline & A. flavus & 45 & 22 & 44 \\
\hline & A. niger & 40 & 17 & 45 \\
\hline & A. heterophyllus & 100 & 15 & Present work \\
\hline
\end{tabular}
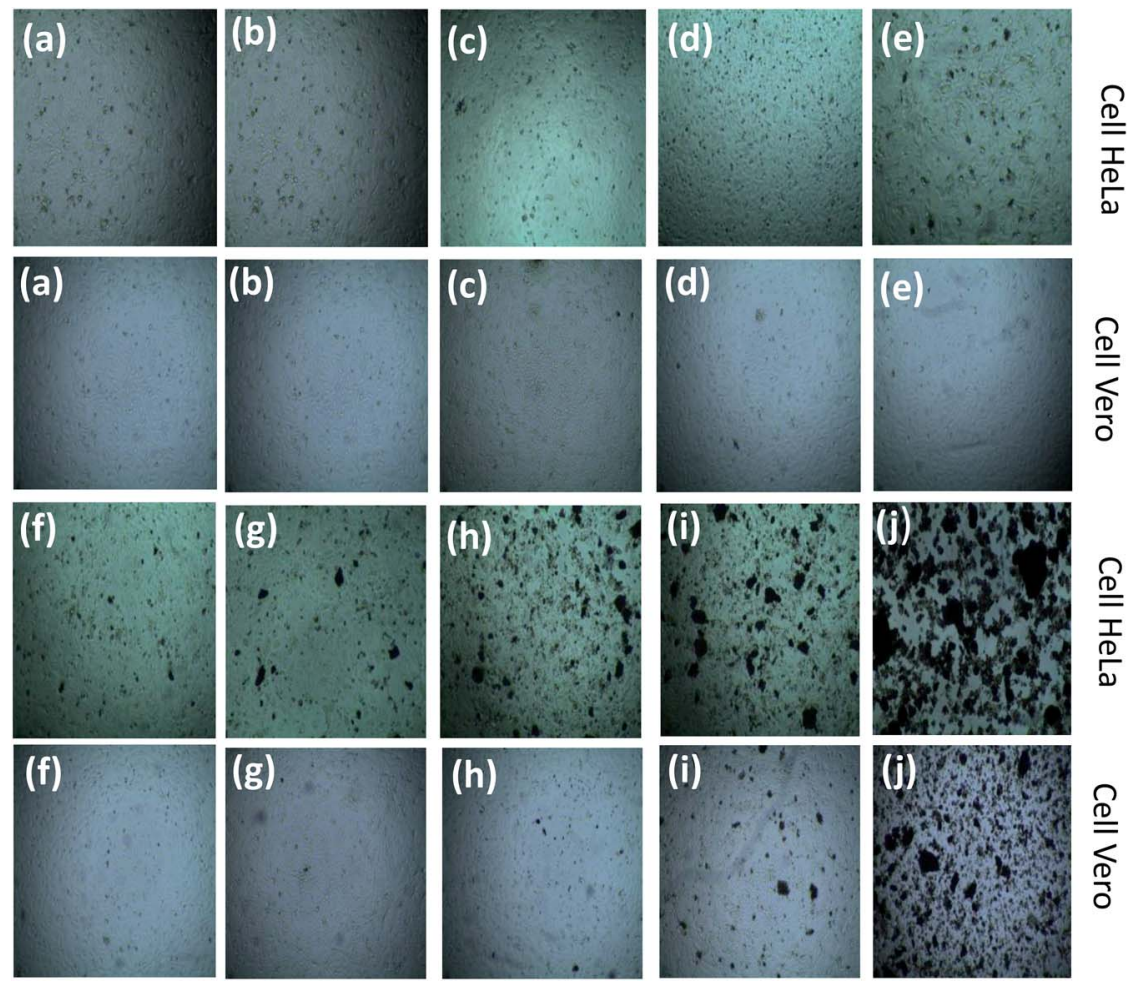

Fig. 8 Phase contrast microscopic images of $\mathrm{TiO}_{2} \mathrm{NP}$ induced cytomorphological changes and growth inhibition of HeLa and Vero cell lines with controls and at different concentrations: (a) control, (b) leaf extract, (c) $20 \mathrm{mg} \mathrm{L}^{-1}$, (d) $50 \mathrm{mg} \mathrm{L}^{-1}$, (e) $100 \mathrm{mg} \mathrm{L}^{-1}$, (f) $500 \mathrm{mg} \mathrm{L}-1$, (g) $1000 \mathrm{mg} \mathrm{L}^{-1}$, (h) $2000 \mathrm{mg} \mathrm{L}^{-1}$, (i) $3000 \mathrm{mg} \mathrm{L}^{-1}$, and (j) $5000 \mathrm{mg} \mathrm{L}^{-1}$.

cytotoxicity observed in the present study could be due to oxidative stress-mediated cellular damage.

\section{Conclusions}

The low-cost, surface modified, green synthesis of $\mathrm{TiO}_{2} \mathrm{NPs}$ was investigated for antibiotic application and in vitro cytotoxicity. The synthesized $\mathrm{TiO}_{2}$ NPs were oxygen non-stoichiometric and surface modified. The dilute ferromagnetic nature of the sample at room temperature fulfilled the criteria of highly efficient materials for biomedical application. The application of
Artocarpus heterophyllus leaf extract surface modified $\mathrm{TiO}_{2}$ NPs against both Gram-positive and Gram-negative bacteria and their comprehensive studies in the literature concluded that the current sample has potential antibiotic activity. The toxicity investigation of surface modified $\mathrm{TiO}_{2} \mathrm{NPs}$ allow them to be used for various applications with concentrations up to $1000 \mathrm{mg} \mathrm{L}^{-1}$. The study of the current sample with HeLa cells implies that this material could be used as an anticancer agent at a concentration of $2000 \mathrm{mg} \mathrm{L}^{-1}$. 


\section{Conflicts of interest}

The authors declare no conflict of interest.

\section{Acknowledgements}

The authors would like to thank the Nanoscience and Technology Research Laboratory and Materials Science Division, Atomic Energy Centre, Dhaka, and Centre for Advance Research in Science, University Dhaka, Dhaka, Bangladesh for providing assistance regarding synthesis and characterization of the samples.

\section{Notes and references}

1 Y. Li, T. J. White and S. H. Lim, J. Solid State Chem., 2004, 177, 1372-1381.

2 N. I. A. Salim, S. A. Bagshaw, A. Bittar, T. Kemmtt, A. J. Mcquillan, A. M. Mills and M. J. Ryan, J. Mater. Chem., 2000, 10, 2358-2363.

3 S. Ito, S. Inoue, H. Kawada, M. Hara, M. Iwaski and H. Tada, J. Colloid Interface Sci., 1999, 216, 59-64.

4 C. J. Barbe, F. Arendse, P. Comte, M. Jirousek, F. Lenzmann, V. Shklover and M. Gratzel, J. Am. Ceram. Soc., 1997, 80, 3157-3171.

5 S. Monticone, R. Tufeu, A. V. Kanaev, E. Scolan and C. Sanchez, Appl. Surf. Sci., 2000, 162, 565-570.

6 S. Boujday, F. Wunsch, P. Portes, J. F. Bocquet and C. C. Justin, Sol. Energy Mater. Sol. Cells, 2004, 83, 421-433.

7 O. Carp, C. L. Huisman and A. Reller, Prog. Solid State Chem., 2004, 32, 33-177.

8 A. M. Ruiz, G. Sakai, A. Cornet, K. Shimanoe, J. R. Morante and N. Yamazoe, Sens. Actuators, B, 2004, 103, 312-317.

9 H. Shi, R. Magaye, V. Castranova and J. Zhao, Part. Fibre Toxicol., 2013, 10, 15.

10 N. Roy, Y. Park, Y. Sohn, K. T. Leung and D. Pradhan, ACS Appl. Mater. Interfaces, 2014, 6, 16498-16507.

11 K.-S. Lin, H.-W. Cheng, W.-R. Chen and J.-F. Wu, J. Environ. Eng. Manage., 2010, 20, 69-76.

12 A. K. M. A. Ullah, A. K. M. F. Kibria, M. Akter, M. N. I. Khan, M. A. Maksud, R. A. Jahan and S. H. Firoz, J. Saudi Chem. Soc., 2017, 21, 830-836.

13 A. Hossain, S. Roy and K. Sakthipandi, Ceram. Int., 2019, 45, 4152-4166.

14 A. K. M. A. Ullah, A. K. M. F. Kibria, M. Akter, M. N. I. Khan, A. R. M. Tareq and S. H. Firoz, Water Conservation Science and Engineering, 2017, 1, 249-256.

15 S. M. Gupta and M. Tripathi, Cent. Eur. J. Chem., 2012, 10, 279-294.

16 M. A. A. Mamun, M. Noor, A. K. M. A. Ullah, M. S. Hossain, M. A. Matin, F. Islam and M. A. Hakim, Mater. Res. Express, 2019, 6, 016102.

17 A. Mbonyiryivuze, S. Zongo, A. Diallo, S. Bertrand, E. Minani, L. L. Yadav, B. Mwakikunga, S. M. Dhlamini and M. Maaza, Phys. Mater. Chem., 2015, 3, 12-17.
18 K. S. Kavitha, B. Syed, D. Rakshith, H. U. Kavitha, H. C. Y. Rao, B. P. Harini and S. Satish, Int. Res. J. Biol. Sci., 2013, 2, 66-76.

19 X. Gao, Y. Cui, R. M. Levenson, L. W. Chung and S. Nie, Nat. Biotechnol., 2004, 22, 969-976.

20 J. M. Streit, T. R. Fritsche, H. S. Sader and R. N. Jones, Diagn. Microbiol. Infect. Dis., 2004, 48, 137-143.

21 A. Coates, Y. Hu, R. Bax and C. Page, Nat. Rev. Drug Discovery, 2002, 1, 895-910.

22 T. M. L. Goerne, M. A. A. Lemus, V. A. Morales, E. G. Lopez and P. C. Ocampo, J. Nanomed. Nanotechnol., 2012, S5, 003.

23 M. Thamima and S. Karuppuchamy, Adv. Sci., Eng. Med., 2014, 6, 1-8.

24 G. Rajakumar, A. A. Rahuman, C. Jayaseelan, T. Santhoshkumar, S. Marimuthu, C. Kamaraj, A. Bagavan, A. A. Zahir, A. V. Kirthi, G. Elango, P. Arora, R. Karthikeyan, S. Manikandan and S. Jose, Parasitol. Res., 2014, 113, 469-479.

25 K. Velayutham, A. Rahuman, G. Rajakumar, T. Santhoshkumar, S. Marimuthu, C. Jayaseelan, A. Bagavan, A. Kirthi, C. Kamaraj, A. A. Zahir and G. Elango, Parasitol. Res., 2012, 111, 2329-2337.

26 R. B. Malabadi, R. K. Chalannavar, N. T. Meti, G. S. Mulgund, K. Nataraja and S. V. Kumar, Res. Pharm., 2012, 2, 18-31.

27 S. Marimuthu, A. A. Rahuman, C. Jayaseelan, A. V. Kirthi, T. Santhoshkumar, K. Velayutham, A. Bagavan, C. Kamaraj, G. Elango, M. Iyappan, C. Siva, L. Karthik and K. V. B. Rao, Asian Pac. J. Trop. Dis., 2013, 6, 682-688.

28 A. C. Nwanya, P. Ugwuoke, P. M. Ejikeme, E. O. Oparaku and F. I. Ezema, Int. J. Electrochem. Sci., 2012, 7, 11219-11235.

29 A. K. M. A. Ullah, M. F. Kabir, M. Akter, A. N. Tamanna, A. Hossain, A. R. M. Tareq, M. N. I. Khan, A. K. M. F. Kibria, M. Kurasaki and M. M. Rahman, $R S C$ Adv., 2018, 8, 37176-37183.

30 M. Akter, M. M. Rahman, A. K. M. A. Ullah, M. T. Sikder, T. Hosokawa, T. Saito and M. Kuasaki, J. Inorg. Organomet. Polym. Mater., 2018, 28, 1483-1493.

31 Y. Yang, X. Wang and L. Li, J. Am. Ceram. Soc., 2008, 91, 632635.

32 G. Liu, H. G. Yang, X. Wang, L. Cheng, H. Lu, L. Wang, G. Q. Lu and H. M. Cheng, J. Phys. Chem., 2009, 113, 21784-21788.

33 M. Sundrarajan, K. Bama, M. Bhavani, S. Jegatheeswaran, S. Ambika, A. Sangili, P. Nithya and R. Sumathi, J. Photochem. Photobiol., B, 2017, 171, 117-124.

34 P. Kalainila, V. Subha, R. S. E. Ravindran and S. Renganathan, Asian J. Pharm. Clin. Res., 2014, 7, 39-43.

35 R. Begum, M. G. Aziz, M. B. Uddin and Y. A. Yusof, Agriculture and Agricultural Science Procedia, 2014, 2, 244-251.

36 H. Fu, X. Ding, C. Ren, W. Li, H. Wu and H. Yang, RSC Adv., 2017, 7, 16513-16523.

37 J. R. Carvajal, Phys. B, 1993, 192, 55-69.

38 Q. Xu, J. Yu, J. Zhang, J. Zhang, J. Zhang and G. Liu, Chem. Commun., 2015, 51, 7950-7953.

39 C. Ma, O. Tschauner, J. R. Beckett, G. R. Rossman and W. Liu, Am. Mineral., 2012, 97, 1219-1225. 
40 Y. Matsumoto, M. Murakami, T. Shono, T. Hasegawa, T. Fukumura, M. Kawasaki, P. Ahmet, T. Chikyow, S. Koshihara and H. Koinuma, Science, 2001, 291, 854-856.

41 Z. M. Tian and S. L. Yuan, Effects of sintering temperature and atmosphere on magnetism in Mn-doped $\mathrm{TiO}_{2}$ bulk samples, Department of Physics, Huazhong University of Science and Technology, Wuhan 430074, PR China, 2007.

42 L. Kvitek, A. Panacek, J. Soukupova, M. Kolar, R. Vecerova and R. Prucek, J. Phys. Chem. C, 2008, 112, S1005825-5834.

43 S. Ahmed, M. Ahmad, B. L. Swami and S. Ikram, J. Adv. Res., 2016, 7, 17-28.
44 G. Rajakumar, A. A. Rauman, S. M. Roopan, V. G. Khanna, G. Elango, C. Kamaraj, A. A. Zahir and K. Velayutham, Spectrochim. Acta, Part A, 2012, 91, 23-29.

45 B. Durairaj, S. Muthu and T. Xavier, Adv. Appl. Sci. Res., 2015, 6, 45-48.

46 P. S. M. Kumar, A. P. Francis and T. Devasena, Journal of Environmental Nanotechnology, 2014, 3, 78-85.

47 K. Soto, K. M. Garzal and E. Murr, Acta Biomater., 2007, 3, 351-358.

48 M. Aktera, M. T. Sikder, M. M. Rahmana, A. K. M. A. Ullah, K. F. B. Hossain, S. Banika, T. Hosokawa, T. Saito and M. Kurasaki, J. Adv. Res., 2018, 9, 1-16. 